Original Research Paper

\title{
Using Permeable Reactive Barriers to Remediate Heavy Metal-Contaminated Groundwater through a Laboratory Column Experiment
}

\author{
${ }^{1,2}$ Somean Yin, ${ }^{1}$ Gemunu Herath, ${ }^{2}$ Sokchhay Heng and ${ }^{3}$ Senajith Kalpage \\ ${ }^{I}$ Department of Civil Engineering, University of Peradeniya, Peradeniya, Sri Lanka \\ ${ }^{2}$ Department of Rural Engineering, Institute of Technology of Cambodia, Phnom Penh, Cambodia \\ ${ }^{3}$ Department of Chemical and Process Engineering, University of Peradeniya, Peradeniya, Sri Lanka
}

Article history

Received: 11-11-2016

Revised: 01-02-2017

Accepted: 09-03-2017

Corresponding Author:

Sokchhay Heng

Department of Rural

Engineering, Institute of

Technology of Cambodia,

Phnom Penh, Cambodia

Email: heng_sokchhay@yahoo.com

\begin{abstract}
Recently, groundwater sources are being polluted by various activities such as agriculture, livestock, decentralized wastewater treatment systems and acid rain. Groundwater can also be polluted by landfill leachate, sewage, mine tailings, non-engineered deep well disposal of liquid waste and seepage from industrial waste lagoons. There are many studies reported contaminated groundwater remediation using Permeable Reactive Barrier systems (PRBs) and many countries happen to use this system to eliminate groundwater contaminants. This study reports the outcomes of the batch and the column test experiments conducted to evaluate the removal efficiency of four heavy metals: $\mathrm{Cd}(\mathrm{II}), \mathrm{Cu}(\mathrm{II}), \mathrm{Fe}(\mathrm{II})$ and $\mathrm{Pb}(\mathrm{II})$ using five locally available reactive materials (in Sri Lanka) with grain sizes less than or equal to $2.0 \mathrm{~mm}$ : Red Soil (RS), Laterite Soil (LS), Bangadeniya Soil (BS), Burnt Clay Tile (BCT) and Coconut Shell Biochar (CSB) as PRB materials. Seven columns (A-G) were filled with the reactive material of CSB (column E) and reactive material mixtures; RS + CSB (column A), LS + CSB (column B), BCT + CSB (column C), BS + CSB (column F), RS + LS (column G), with a weight ratio of 50:50 and RS + BCT + CSB (column D) with a weight ratio of $100 / 3: 100 / 3: 100 / 3$. The results showed that the reactive materials filled in column $\mathrm{A}, \mathrm{B}, \mathrm{D}, \mathrm{F}$ and $\mathrm{G}$ removed the metal concentrations, with a removal efficiency of over $90 \%$, except $\mathrm{Cd}$ in the column with BCT + CSB mixture. Considering both the removal efficiency and the hydraulic conductivity of the columns, materials in column $\mathrm{A}, \mathrm{B}, \mathrm{D}$ and $\mathrm{F}$ are more effective than the others as PRB adsorbents for heavy metal remediation, while columns $\mathrm{C}$ and $\mathrm{E}$ have lower removal efficiency.
\end{abstract}

Keywords: Groundwater Pollution, Heavy Metal, Reactive Material, Permeable Reactive Barrier, Column Experiment

\section{Introduction}

There are many heavy metal elements present in the earth's crust as well as metal elements released from industrial effluents such as microelectronics, electroplating, battery manufacture, metallurgical and fertilizer industries, or acid rain breaking down soils releasing heavy metals into streams, lakes, rivers and groundwater (Munagapati et al., 2009). These metals can dissolve in groundwater by natural processes or degradation of soil $\mathrm{pH}$. Additionally, heavy metals also are released from inappropriate landfill and sewage management, leaching from mine tailings, non-engineered deep well injections and seepage from industrial waste lagoons (Evanko and Dzombak, 1997). Through untreated landfill leachate, depending on the type of landfill, metal contaminants such as $\mathrm{Cd}$, $\mathrm{Hg}, \mathrm{Ni}, \mathrm{Mn}, \mathrm{Cu}, \mathrm{Zn}, \mathrm{Pb}, \mathrm{As}$ and $\mathrm{Fe}$ are often released 
to the environment. Heavy metals have an atomic density greater than $4,000 \mathrm{~kg} / \mathrm{m}^{3}$ or equal to 5 times more than that of water (Garbarino et al., 1995).

Many researchers have found that though some of the metals play as essential micronutrients for living beings, most heavy metals at higher concentrations give extremely harmful effects to humans, animals and plants because of their high toxicity and biological accumulation in the body (Soylak et al., 1999; Arain et al., 2008; Kazi et al., 2009; Afridi et al., 2009; Bermudez et al., 2011). Moreover, heavy metals may cause diseases to humans such as lung damage, renal damage, Wilson's disease (neurological or psychiatric symptoms of liver disease, compounded with heavy metal deposits), insomnia, dermatitis, nausea, chronic asthma, headache, dizziness, rapid respiration, coughing and cancer, etc. (Meena et al., 2005; Guzel et al., 2008).

In recent years, there are many technologies and methods used to remove heavy metals from groundwater or wastewater such as adsorption, chemical precipitation, ion exchange and membrane. These technologies have their own different advantages and disadvantages to remediate heavy metals contaminated groundwater or surface water. However, when heavy metal ions co-exist in the form of cations and anions, Han et al. (2015) reported many difficulties in treating them.

For the conventional pump-and-treat technology being utilized for remediating polluted groundwater, its cleanup goals hardly show achieving targets. Moreover, the pump-and-treat technology is a passive treatment operation where it needs much more independence of external labor and energy inputs.

The Permeable Reactive Barrier (PRB) on the other hand is a novel technology used worldwide for remediation of contaminated groundwater. This technology uses adsorption, chemical precipitation and degradation processes in combination to generate physical, chemical or biochemical reaction between contaminants and reactive materials contained in barriers to facilitate waste removal (Thiruvenkatachari et al., 2008). Further, due to its promising removal efficiencies, easier maintenance, longer lifespan (10-20 years), environmentally friendly behaviors and low cost make this system more attractive (Woinarski et al., 2006; Dong et al., 2009). Therefore, PRB is one of the technologies used as in-situ remediation method for heavy metals contaminated groundwater, chlorinated organic, phosphorus, etc. This method was firstly applied in a field study at the Canadian Forces Base, Borden (O’Hannesin and Gillham, 1998).

Bone (2012) has shown that the total 624 publications on PRBs were made between 1999 and 2009. PRB method is worldwide used to carry out the treatment of contaminated groundwater and surface water (Blowes et al., 1998; Conca et al., 2002; Kober et al., 2002). The concept of PRBs is to act as a permeable barrier packed with reactive materials that intercept the path of the contaminated groundwater flow path to treat the contaminant plume. There are many advantages and limitations of PRB which were identified by Carey et al. (2002) and Henderson and Demond (2007) (Table 1).

Moreover, the PRBs can be an attractive option for developing countries like Cambodia, India and Sri Lanka to treat contaminated groundwater where risk of contamination is high due to widespread solid waste open dumps. For instance, PRBs was used to remove arsenic from groundwater along river banks of the Mekong River in Cambodia (Marie et al., 2009). However, the high costs of reactive materials make the system unaffordable to developing countries.

Table 1. Advantages and limitations of permeable reactive barrier

\begin{tabular}{ll}
\hline No. & Advantages \\
\hline 1 & $\begin{array}{l}\text { Relatively cheap passive technology, i.e., inexpensive but } \\
\text { effective reactive. Low energy cost; little or no disposal } \\
\text { costs for treated wastes; relatively low maintenance and } \\
\text { monitoring costs with the exception of initial installation }\end{array}$ \\
2 & $\begin{array}{l}\text { Allows for treatment of multiple contamination plumes si } \\
\text { more than one barrier can be used }\end{array}$ \\
3 & Ability to treat a wide range of contaminants \\
4 & $\begin{array}{l}\text { The aboveground of the contaminated site can be put to } \\
\text { profitable use while treatment is ongoing }\end{array}$ \\
5 & $\begin{array}{l}\text { No cross-media contamination since contaminants is not } \\
\text { brought to the surface }\end{array}$ \\
$6 \quad \begin{array}{l}\text { Requires occasional monitoring to ensure that barriers } \\
\text { are functioning properly }\end{array}$ \\
7 & $\begin{array}{l}\text { Obviates the handling and loss of large volumes of } \\
\text { groundwater }\end{array}$
\end{tabular}
Limitations

Only contaminants flowing in the direction of the barrier can be treated

Requires proper characterization of the site, aquifer, hydrogeological conditions and accurate delineation of the contaminant plume prior to barrier installation Restricted to plumes not deeper than $20 \mathrm{~m}$ beneath the ground surface

A limited field data concerning longevity of barriers

Below-ground structures (e.g., services, foundations) may present problems in construction and performance Reactive media may have to be removed or be replaced during operation

May require long-term monitoring, particularly in the case of persistent contaminants or very slow groundwater flow 
The reactive material is the main adsorbent used in Permeable Reactive Barrier system to remove contaminants from groundwater. Many researchers have found various possible reactive materials for organic and inorganic remediation. The commonly used reactive materials, relying on their different high removal ability for contaminated water, are ZeroValent Iron (ZVI) (Liu et al., 2013; Obiri-Nyarko et al., 2014), zeolite (Kovalick and Kngscott, 1995; Vignola et al., 2011), activated carbon (Natale et al., 2007), Peat (Kao and Yang, 2000). Among these materials, ZVI is widely used in PRBs to clean contaminated groundwater and surface water (Obiri-Nyarko et al., 2014). The review of Guerin et al. (2002) and Gibert et al. (2011) showed that there are more than 200 PRBs built worldwide in different scenarios of contamination mostly used ZVI.

The main objective of this research is to evaluate the reactive materials which is locally available in Sri Lanka as candidate materials to be used in Permeable Reactive Barrier system (PRBs) for the heavy metals contaminated groundwater remediation. The specific objectives are (1) to examine the hydraulic conductivity of single and mixed reactive materials, (2) to define the removal efficiency of the heavy metals on the single and mixed reactive materials conducted with laboratory column experiment and (3) to analyze the heavy metals $(\mathrm{Cd}, \mathrm{Cu}, \mathrm{Fe}$ and $\mathrm{Pb})$ leaching from raw reactive materials.

\section{Materials and Methods}

\section{Physical Properties of the Reactive Material Mixes}

Reactive material is the main adsorbent used in Permeable Reactive Barrier system (PRBs) to facilitate the removal of contaminants from groundwater. Main criteria for the selection of material for this study are local availability, reactivity efficiency, mechanical stability, cost effective, hydraulic conductivity performance, environmental compatibility and safety. Red Soil (RS), Laterite Soil (LS), Bangadeniya Soil (BS), Burnt Clay Tile (BCT) and Coconut Shell Biochar (CSB) were used as the reactive materials in the PRBs. These materials are abundant in Sri Lanka and their cost is very low comparing to other commercial reactive materials.

Physical properties of the material fills are important for designing the column experiment and installing PRB. There are three tests to determine the physical properties of the material fill. These are a gradation test for determining the particle size distribution, the standard compaction test for determining the density and moisture content of the fill and the falling head test for determining the hydraulic conductivity. These testes are essential for estimating the quantity $(\mathrm{kg})$ of PRB material packed into the column pipe as well as PRB system. Particularly, the dry density and moisture content were applied to calculate hydraulic conductivity $(K)$, so that one can select the appropriate passed flow cross packed material in each column. The moisture content in this experiment refers to how much water is added and mixed with PRB material for packing into the column experiment.

A sieve analysis (gradation test) is a commonly used method in civil engineering to determine the particle size distribution of granular materials. Five samples of $\mathrm{CSB}, \mathrm{RS}, \mathrm{LS}, \mathrm{BCT}$ and BS were dried in an oven at $105^{\circ} \mathrm{C}$ for $24 \mathrm{~h}$. Each sample was shaken so that the sample particles passed through many mesh sieve layers starting from $2.000,1.700,1.180,0.850,0.600$, $0.425,0.250,0.150 \mathrm{~mm}$, until $0.075 \mathrm{~mm}$. The total mass of each sample is $1,000 \mathrm{~g}$. After being sieved for four minutes, the samples retaining on each sieve mesh size were weighed. The percentages of the sample retaining and passing were calculated as:

$$
\begin{aligned}
& R=\frac{M_{\mathrm{C}}}{M_{\mathrm{t}}} \times 100 \\
& P=100-R
\end{aligned}
$$

Where:

$R=$ The percentage of material retained on the sieve $(\%)$

$M_{C}=$ The mass accumulation of material retained on the sieve $(\mathrm{g})$

$M_{t}=$ The total mass of materials $(\mathrm{g})$

$P=$ The percentage of material passing through the sieve $(\%)$

The standard compaction test (Moisture-Density Relation) is the most common practice in soil mechanic field. The objective of this test is to determine the relationship between the optimum moisture content $(W)$ and dry density $\left(\rho_{\mathrm{d}}\right)$. The single and mixture samples passing through a sieve of 2.0 $\mathrm{mm}$ were selected. The samples were dried in the air for $24 \mathrm{~h}$. Moreover, the required weight of the sample is approximately $2.5 \mathrm{~kg}$.

Water was added into the sample and mixed thoroughly until the sample appeared a uniform color. The Proctor Mold was filled with three equal layers of the mixed sample and each layer was compacted by using $2.5 \mathrm{~kg}$ hammer falling at a distance of $30 \mathrm{~cm}$ from the surface of each layer. Each layer also received 27 uniformly distributed blows. The compacted sample within the mold is weighed and recorded the mass. The mass of the wet sample was determined by subtracting the weight of the mold. The two samples were withdrawn from the top and bottom of the specimen 
and put into small bowls and then dry in the oven at $105^{\circ} \mathrm{C}$ for $24 \mathrm{~h}$. The small bowls, wet samples and dried samples were weighed and recorded in gram $(\mathrm{g})$. The test was repeated with lesser compacted sample masses until a peak value was reached. The moisture content $W(\%)$ and dry density $\left(\rho_{d}\right)$ were calculated as:

$$
\begin{gathered}
W=\frac{m_{\mathrm{w}}}{m_{\mathrm{ws}}} \times 100 \\
\rho_{\mathrm{d}}=\frac{\rho_{\mathrm{b}} \times 100}{100+W}
\end{gathered}
$$

Where:

$$
\begin{aligned}
& W=\text { The soil moisture content }(\%) \\
& m_{\mathrm{w}}=\text { The mass of water }(\mathrm{g}) \\
& m_{\mathrm{ws}}=\text { The mass of wet sample }(\mathrm{g}) \\
& \rho_{\mathrm{d}}=\text { The dry density }\left(\mathrm{Mg} / \mathrm{m}^{3}\right) \\
& \rho_{\mathrm{b}}=\text { The bulk density }\left(\mathrm{Mg} / \mathrm{m}^{3}\right)
\end{aligned}
$$

The falling head test method is commonly used for fine-grained soils whose hydraulic conductivity $(K)$ ranging from $10^{-2}$ to $10^{-6} \mathrm{~cm} / \mathrm{s}$. Furthermore, this method is suitable to determine hydraulic conductivity of the reactive materials mix, both single and mixed samples in this study. The hydraulic conductivity was measured by using the fixed permeable wall under a falling head condition.

The sample mold was connected to a standpipe which provides the head of water and the means of measuring the quantity of water flows through the sample. A reactive material sample was compacted into the mold $(11.85 \mathrm{~cm}$ in height and $9.95 \mathrm{~cm}$ in diameter). The hydraulic conductivity test was conducted with three different values of the moisture content (minimum, optimum and maximum values). Then the mold with compacted sample was soaked in a water basket and kept for a minimum period of 1-2 days in order to allow the sample become fully saturated. The air bubbles were completely released from the standpipe connected with mold specimen.

After the sample was fully saturated, the standpipe was filled with the tap water up to the starting point. Then the test was started by allowing the water to flow up-down through the sample until the water in the standpipe reached a limited lower level. The time reading was recorded every $10 \mathrm{~cm}$ of dropping water in the standpipe by using a chronometer. It was repeated until the time reading varied within 5-15\%; otherwise, it will not be accepted. Based on the reading results the hydraulic conductivity can be computed as:

$$
K=\frac{a}{A} \times \frac{L}{\Delta t} \times \ln \left(\frac{h_{1}}{h_{2}}\right)
$$

Where:

$K=$ The hydraulic conductivity $(\mathrm{cm} / \mathrm{s})$

$a=$ The cross section area of stand pipe $\left(\mathrm{cm}^{2}\right)$

$A=$ The cross section area of mold specimen $\left(\mathrm{cm}^{2}\right)$

$L \quad=$ The height mold specimen $(\mathrm{cm})$

$\Delta t=$ The time of water drop through the specimen (s)

$h_{1}, h_{2}=$ Respectively the water drop level at the beginning and the end of reading time $(\mathrm{cm})$

\section{Preparation of Synthetic Heavy Metal Solutions}

The synthetic heavy metal contaminated water contains the desired concentrations of $20 \mathrm{mg} \mathrm{L}^{-1}$ of $\mathrm{Cu}^{+2}, 20 \mathrm{mg} \mathrm{L}^{-1}$ of $\mathrm{Fe}^{+2}, 5 \mathrm{mg} \mathrm{L}^{-1}$ of $\mathrm{Pb}^{+2}$ and $5 \mathrm{mg}$ $\mathrm{L}^{-1}$ of $\mathrm{Cd}^{+2}$ that were prepared from Copper Sulfate Monohydrate $\left(\mathrm{CuSO}_{4} .5 \mathrm{H}_{2} \mathrm{O}\right)$, Iron Sulfate Monohydrate $\left(\mathrm{FeSO}_{4} .7 \mathrm{H}_{2} \mathrm{O}\right)$, Lead Nitrate $\left(\mathrm{Pb}\left(\mathrm{NO}_{3}\right)_{2}\right)$ and Cadmium Nitrate Monohydrate $\left(\mathrm{Cd}\left(\mathrm{NO}_{3}\right)_{2} \cdot \mathrm{H}_{2} \mathrm{O}\right)$. It should be noted that the stock solution contains all metals together. The quantity of each chemical required to prepare the desired concentration of each heavy metal was calculated as:

$M=C_{\mathrm{C}} \times$ Purity of chemical $(\%)$

$C_{\mathrm{C}}=\frac{C_{m} \times M_{C}}{M_{m} \times 1000}$

Where:

$M=$ The mass of chemical $(\mathrm{g})$

$C_{\mathrm{C}}=$ The concentration of chemical $(\mathrm{g} / \mathrm{l})$

$C_{\mathrm{m}}=$ The concentration of heavy metal (mg/l or ppm)

$M_{\mathrm{C}}=$ The molar mass of chemical $(\mathrm{g} / \mathrm{mol})$

$M_{\mathrm{m}}=$ The molar mass of heavy metal $(\mathrm{g} / \mathrm{mol})$

\section{Analysis of Leaching of Heavy Metals from Reactive Materials}

There are four adsorbents of heavy metals $(\mathrm{Cu}, \mathrm{Fe}$, $\mathrm{Pb}$ and $\mathrm{Cd}$ ) which were used for the analysis and their sorptivities were checked with CSB, RS, LS, BCT and BS. Five grams of each sample was mixed with 100 $\mathrm{ml}$ of distilled water in $250 \mathrm{~mL}$ PTFE flasks and then shaken at $240 \mathrm{rpm}$ for $4 \mathrm{~h}$ using a shaking incubator. The aqueous phase and suspended solid were then separated by centrifuging with refrigerated ultra at $16,000 \mathrm{rpm}$ for $10 \mathrm{~min}$ at a temperature of $20^{\circ} \mathrm{C}$. To determine the concentrations of heavy metal, the suspended solids were removed filtering through 0.45 $\mu \mathrm{m}$-pore-size Watman membrane filter paper. Filtered samples were tested for $\mathrm{pH}$. The $10 \mathrm{~mL}$ of filtered aqueous samples were preserved at $4^{\circ} \mathrm{C}$ prior to the metal analysis by using AAS7000, SHIMADZU, Japan. 


\section{Column Experiments}

The amounts of PRB materials required to fill $(\mathrm{CSB}, \mathrm{RS}+\mathrm{CSB}, \mathrm{LS}+\mathrm{CSB}, \mathrm{BS}+\mathrm{CSB}, \mathrm{BCT}+\mathrm{CSB}$ and $\mathrm{RS}+\mathrm{BCT}+\mathrm{CSB}$ ) columns were computed as:

$$
M=\gamma_{d} \times V \times W
$$

Where:

$M=$ The required weight of reactive material $(\mathrm{g})$

$\gamma_{\mathrm{d}}=$ The dry buld density of sample $\left(\mathrm{g} / \mathrm{m}^{3}\right)$

$V=$ The volume of column packing $\left(989.30 \mathrm{~cm}^{3}\right)$

$W=$ The moisture content of maximum hydraulic conductivities $(\%)$

The column experiments were conducted by using the black cylinder PVC pipe which is of $50 \mathrm{~cm}$ long with an internal diameter of $7.1 \mathrm{~cm}$ (Fig. 1). In this experiment, there were seven columns (A-G); each column consists of three sampling ports $(0.4 \mathrm{~cm}$ of inner diameter plastic tubes with $2 \mathrm{~cm}$ long) inserted along one side of the column located at $5 \mathrm{~cm}$ (inlet), $15 \mathrm{~cm}$ (port 2) and $25 \mathrm{~cm}$ (outlet) from the bottom of each column. The bottom of each column was compacted $5 \mathrm{~cm}$ of sand (1-2 $\mathrm{mm}$ grain size) to filter out the suspended solid and to provide a uniform flow across each column. A fine screen was placed on the top of the sand layer to prevent the compacted reactive material particles filling in the pore sand layer. The single and mixed reactive materials were filled and manually compacted on the sand layer in each column up to a height of $25.0 \mathrm{~cm}$. A $5 \mathrm{~cm}$ of the sand layer (1-2 mm grain size) was then placed on the top of the compacted material for preventing the fine reactive material flow out. The PRB materials were filled and compacted into the column following the procedure: (1) Weigh the reactive materials for the first layer of $10 \mathrm{~cm}$, the second layer of $10 \mathrm{~cm}$ and the last layer of $5 \mathrm{~cm}$; (2) Compact manually the reactive material layer by layer in each column until reaching the desired height ( $25 \mathrm{~cm}$ of layer).

A closed container of 501 was used to fill the synthetic heavy metal solution and placed it at $2.5 \mathrm{~m}$ high to get the desired flow rate. A $1.0 \mathrm{~cm}$ inner diameter polyethylene tubes was used to deliver the heavy metal solutions to a shearing pipe with seven ports which passing continuously the solutions to each column at the bottom side in the direction bottom-up (Fig. 1). In addition, a white T-valve was used to control the flow from the tank and black small valves were used to control the inflow (influent) and outflow (effluent) of each column.
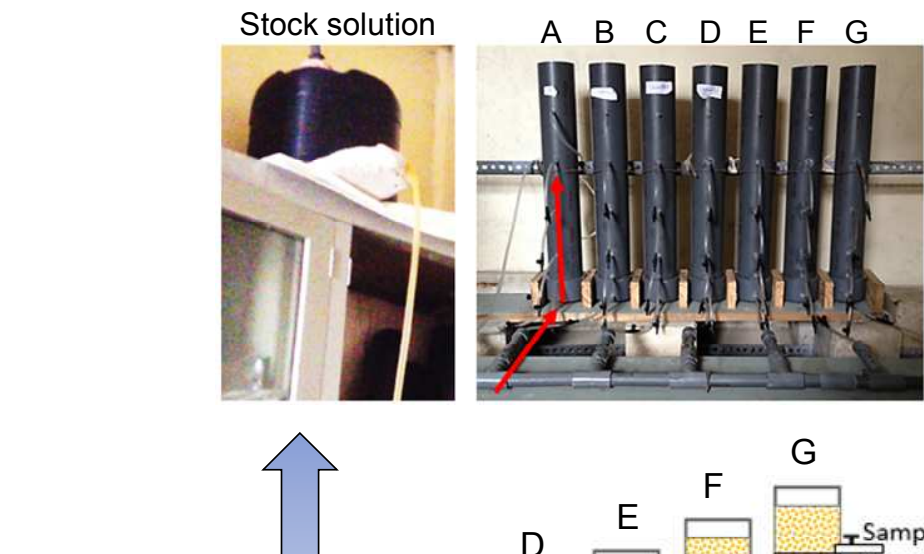

G

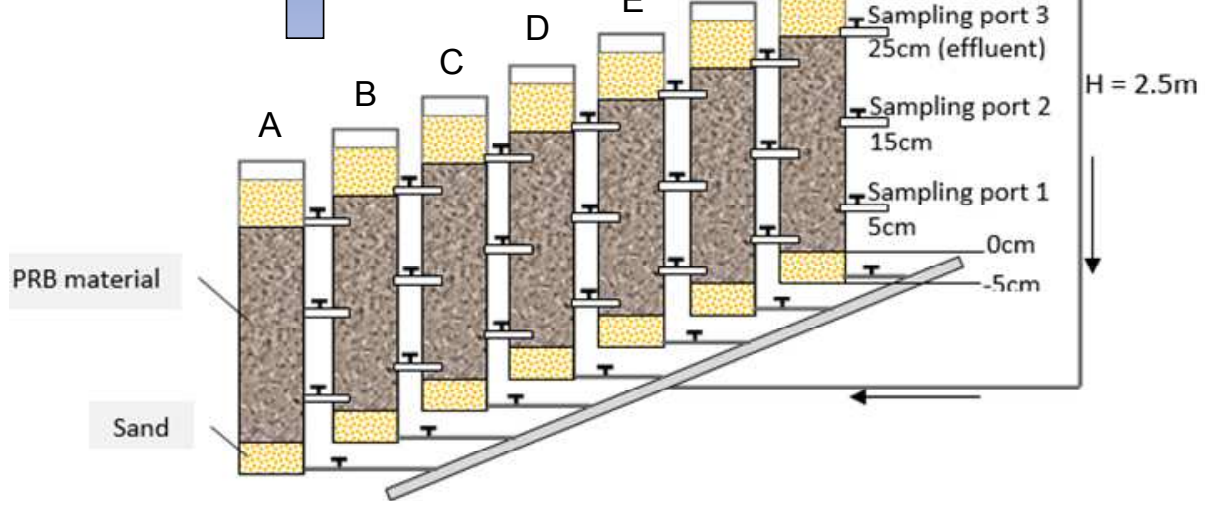

Fig. 1. Schematic diagram of packed bed columns with reactive materials in the Permeable Reactive Barrier 
Prior to each experiment, all columns were soaked and flushed with distilled water until the compacted reactive materials in each column getting fully saturated. After saturation, the valves at the inlet of all columns were opened to release the distilled water. The synthetic solution was then flushed into each column from the bottom (influent) at a flow rate of approximately 1.0 $\mathrm{ml} / \mathrm{min}$ using the falling head method under gravitational flow. However, the flow rate may vary among the column due to a different porosity/hydraulic conductivity. Bottles were used to collect the effluent water samples from three column ports periodically for the heavy metal concentrations analysis $\left(\mathrm{Cu}^{+2}, \mathrm{Fe}^{+2}, \mathrm{~Pb}^{+2}\right.$ and $\left.\mathrm{Cd}^{+2}\right)$ using Atomic Adsorption Spectrophotometer (AAS7000, SHIMADZU, Japan). The flow rates of each column were measured and recorded weekly. All experiments were carried out in the same room and operated simultaneously.

Atomic Adsorption Spectrophotometer is used to measure the concentration of heavy metals such as Manganese (Mn), Iron (Fe), Nickel (Ni), Copper $(\mathrm{Cu})$, Zinc $(\mathrm{Zn})$, Cadmium $(\mathrm{Cd})$, Lead $(\mathrm{Pb})$, Sodium $(\mathrm{Na})$, Potassium (K), Magnesium $(\mathrm{Mg})$ and Calcium $(\mathrm{Ca})$. The technique of this machine is used by the flame atomic spectrometry to determine the quantity of these elements. The sample solutions were filtered through a $0.45 \mu \mathrm{m}$ diameter of micro-filter paper, then stored at $4{ }^{\circ} \mathrm{C}$ prior to the analysis. The filtered aqueous samples were thoroughly removed the suspended solids to avoid clogging in the nebulizer during the analysis. The $\mathrm{pH}$ was also measured by a $\mathrm{pH}$ meter after aqueous samples were collected.

\section{Results and Discussion}

\section{Physical Properties of the Raw Reactive Materials}

The particle size distribution of each reactive material selected were determined. According to the results of the sieving test, the percentage of passing particles was calculated. The particle-size distribution curve was plotted in Fig. 2. It is important to use these curves to pre-identify the hydraulic conductivity of materials. Furthermore, knowing the particle size distribution, it is easy to improve the hydraulic conductivity of a mixture by changing the mixed proportion of CSB with the other reactive materials.

In this research, the compaction test was carried out to determine the optimum moisture contents to achieve the maximum dry density. Having at least a $90 \%$ to $92 \%$ of maximum dry density at the PRB minimizes settlement issues when in use. The dry density was plotted versus the moisture content, generally called the compaction curve (Fig. 3). The test conducted on CSB was very difficult because it is rich of ash contents. The particles were easily damaged and its particle has a high adsorption capacity of water. However, the experiment was done acceptably. The results showed that through not a very visible peak, the maximum dry density of CSB is $0.842 \mathrm{Mg} / \mathrm{m}^{3}$, smaller than the other sample mixtures: $1.12 \mathrm{Mg} / \mathrm{m}^{3}$ for BCT + CSB, $1.257 \mathrm{Mg} / \mathrm{m}^{3}$ for RS + CSB, $1.29 \mathrm{Mg} / \mathrm{m}^{3}$ for $\mathrm{LS}+$ $\mathrm{CSB}, 2.119 \mathrm{Mg} / \mathrm{m}^{3}$ for $\mathrm{RS}+\mathrm{LS}, 1.235 \mathrm{Mg} / \mathrm{m}^{3}$ for $\mathrm{BS}+$ $\mathrm{CSB}$ and $1.354 \mathrm{Mg} / \mathrm{m}^{3}$ for $\mathrm{RS}+\mathrm{BCT}+\mathrm{CSB}$. In contrast, its Optimum Moisture Content (OMC) is $46.25 \%$ greater than that of the other samples (Fig. 3).

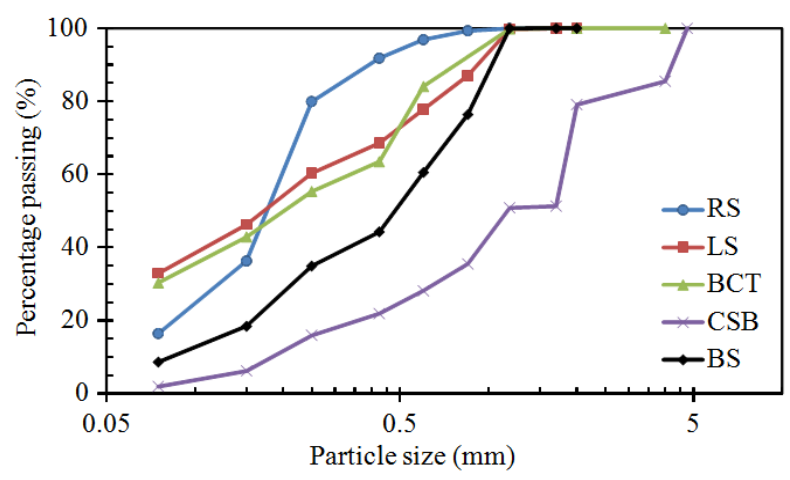

Fig. 2. Particle size distribution of raw reactive materials

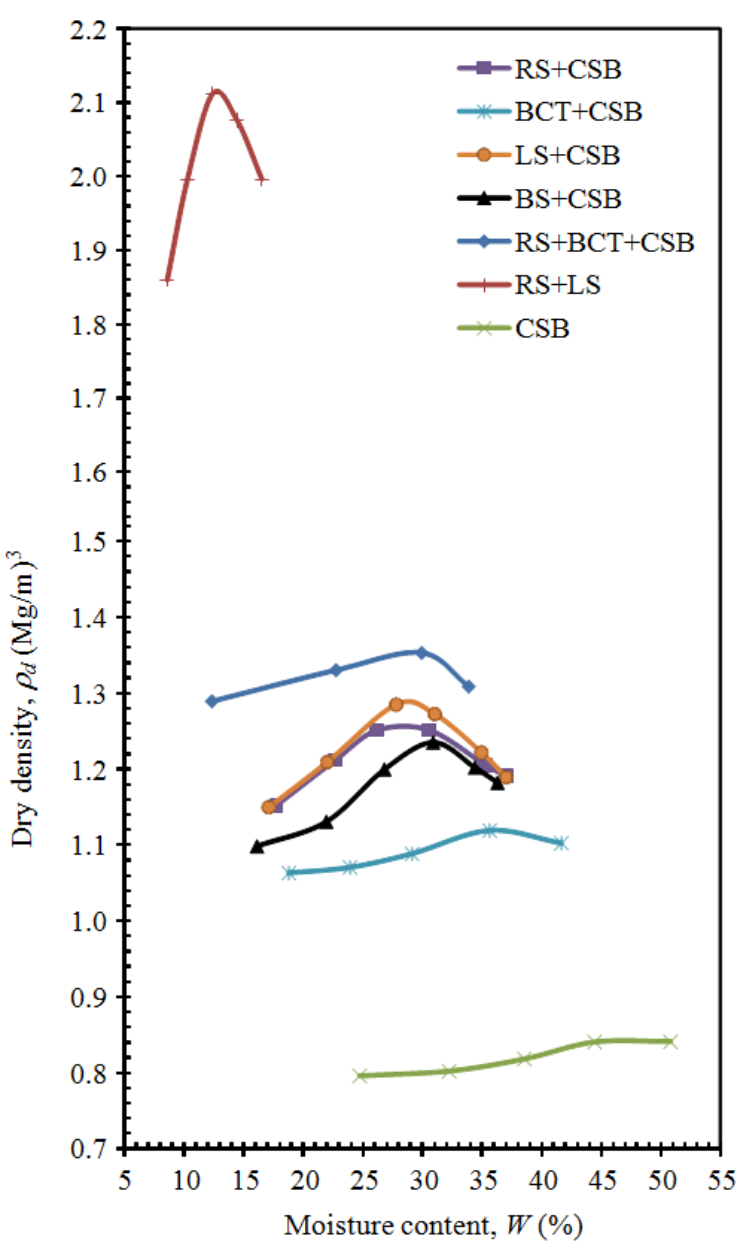

Fig. 3. Compaction curve of reactive raw materials 
The hydraulic conductivity of each material mix at different moisture and density was determined by using the falling head permeability test. The main objective of this test was to find out the appropriate permeable conductivity $(K)$ whose limitation is higher or equal to $10^{-4} \mathrm{~cm} / \mathrm{s}$. The $K$ value has a function with the moisture contents (Fig. 4). There are three values of $K$ which were selected for the study: minimum, optimum and maximum value. The results showed that the hydraulic conductivity of each sample increases when moisture content decreases (Fig. 4). However, there were only two samples, CSB and BCT + CSB, which had hydraulic

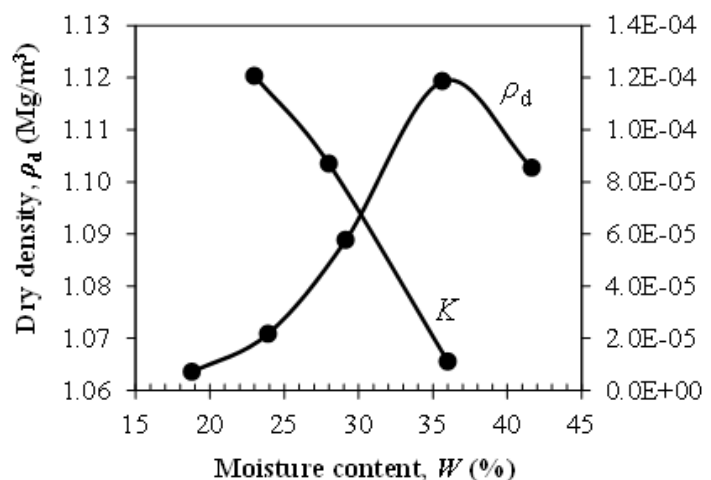

(a)

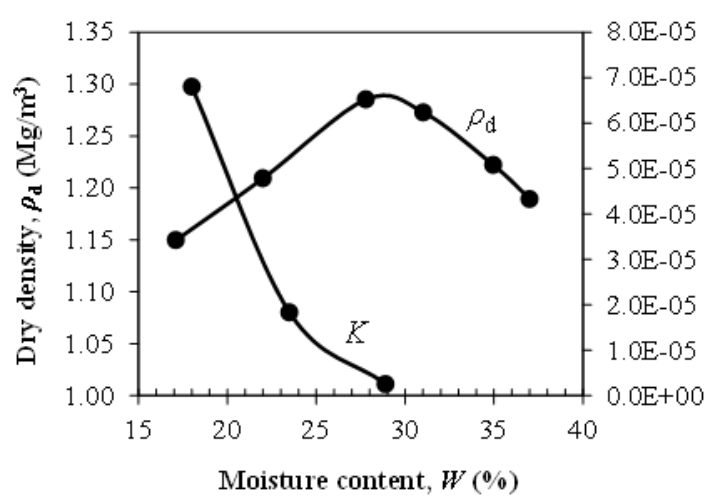

(c)

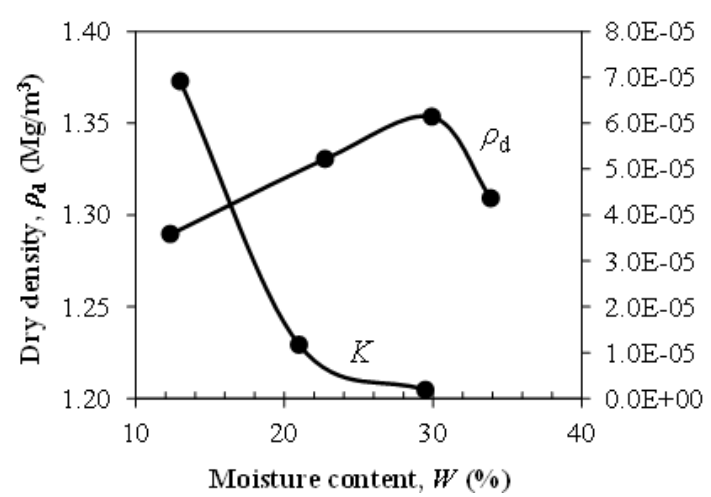

(e) conductivities $(K)$ larger than the limited value of $10^{-4}$ $\mathrm{cm} / \mathrm{s}$, i.e., CSB has a hydraulic conductivity of about $1.4 \times 10^{-4} \mathrm{~cm} / \mathrm{s}$ and BCT + CSB has $1.2 \times 10^{-4} \mathrm{~cm} / \mathrm{s}$, while the other mixture samples have a $K$ value less than their limit value $\left(10^{-4} \mathrm{~cm} / \mathrm{s}\right)$.

\section{Heavy Metal Leaching from Raw Materials}

The leaching of heavy metals from the raw reactive materials was also considered as an important factor in selection. The candidate reactive materials shall release excess contaminants when in use.

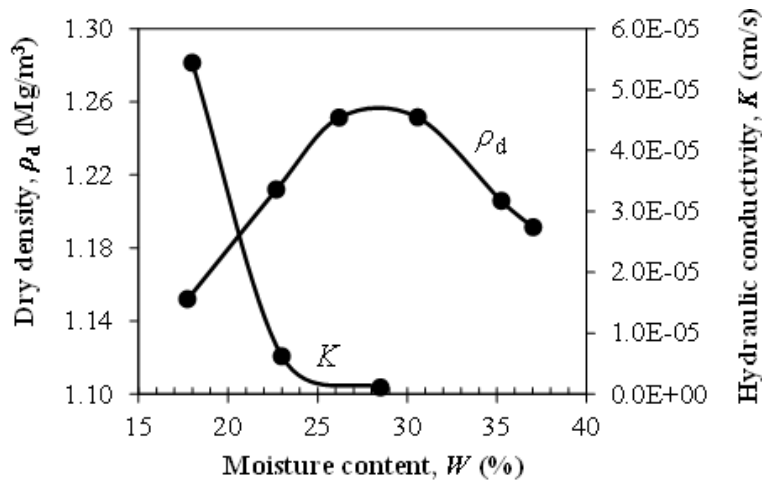

(b)

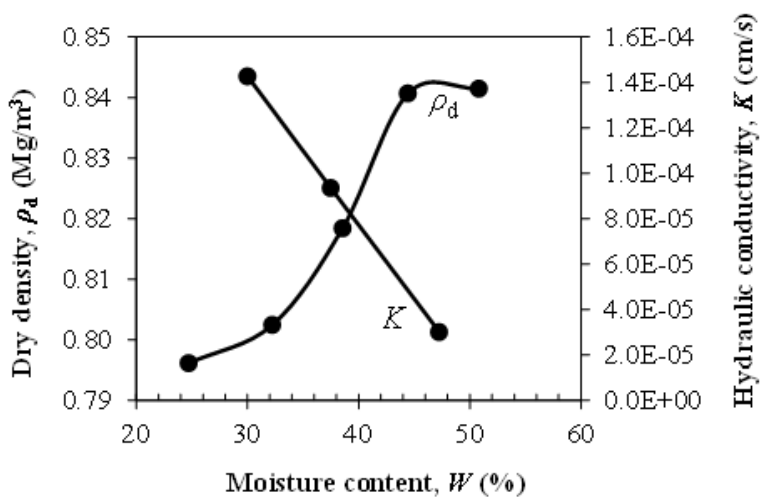

(d)

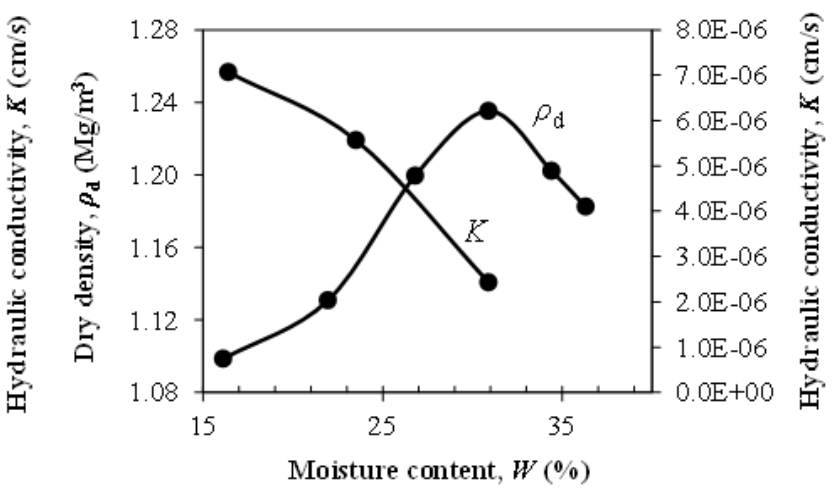

(f)

Fig. 4. Relationship between dry density/hydraulic conductivity and moisture content of raw reactive materials (a) BCT $+\mathrm{CSB}$; (b) RS + $\mathrm{CSB}$; (c) LS + CSB; (d) CSB; (e) BCT + CSB + RS; (f) BS + CSB 
Leaching tests were carried out for all five selected reactive materials: $\mathrm{RS}, \mathrm{LS}, \mathrm{BS}, \mathrm{BCT}$ and $\mathrm{CSB}$ at the Environmental Laboratory, Faculty of Civil Engineering, University of Peradeniya, Sri Lanka.

As shown in Fig. 5, RS has the highest concentration of leaching $\mathrm{Fe}(\mathrm{II}), 0.5103 \mathrm{ppm}$, followed by BS and BCT releasing $0.3297 \mathrm{ppm}$ and $0.2015 \mathrm{ppm}$, respectively. CSB and LS has a very low $\mathrm{Fe}(\mathrm{II})$ leaching, $0.0210 \mathrm{ppm}$ and $0.0093 \mathrm{ppm}$, respectively. Comparing with past studies, the leaching Fe(II) of RS and LS of the present study are higher (Kaandeepan et al., 2012). However, the Fe(II) levels in all samples are within the $1.0 \mathrm{ppm}$ maximum permissible levels specified in Sri Lankas' Standards for potable water SLS 614, 1983. Moreover, the testes show RS had the smallest Cd(II) leaching (0.0012 ppm). BCT, BS, CSB and LS leached small amounts of Cd(II), 0.0035, $0.0030,0.0021$ and $0.0018 \mathrm{ppm}$ respectively; values are less than the SLS 614 maximum permissible level of $0.005 \mathrm{mg} \mathrm{L}^{-1}$. On the other hand, leaching $\mathrm{Cd}(\mathrm{II})$ in this study was found to be different to that of previous studies which did not find leaching Cd from RS and LS (Kaandeepan et al., 2012). The leaching of $\mathrm{Pb}$ was found to be higher than its maximum permissible level of 0.05 ppm, while $0.2191,0.2068,0.2001,0.1882$ and 0.1635 ppm leached from BS, RS, BCT, CSB and LS, respectively. Furthermore, $\mathrm{Pb}(\mathrm{II})$ leaching from RS and LS is much higher than one recorded in previous studies, $0.0077 \mathrm{ppm}$ and $0.0091 \mathrm{ppm}$ respectively, possibly because of the site of RS collection close to a motorway. The small amount of $\mathrm{Cu}$ (II) leaching from RS, BS, CSB, LS and BCT PRB recorded 0.0140 ppm, 0.0123 ppm, $0.0089 \mathrm{ppm}, 0.0078 \mathrm{ppm}$ and $0.0078 \mathrm{ppm}$, respectively (Fig. 5). Compared to 1.5 ppm of $\mathrm{Cu}$ (II), the maximum permissible level, there is no toxicity of $\mathrm{Cu}$ in the PRB materials. Additionally, the measurement of $\mathrm{pH}$ showed the CSB gives the highest value among the materials.

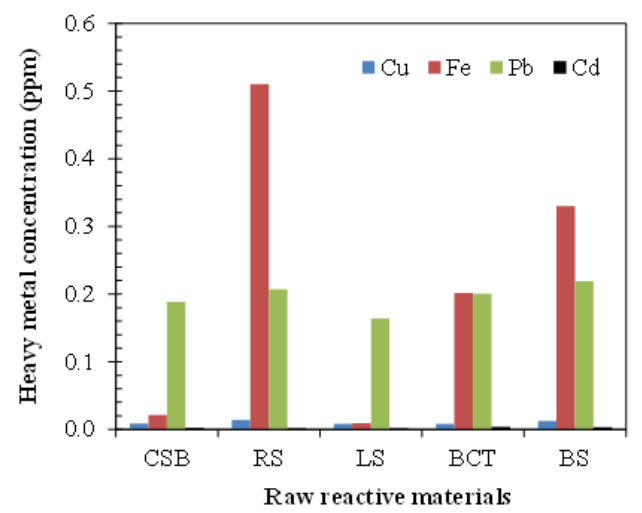

Fig. 5. Heavy metal concentration leaching from raw reactive materials. The concentration of $\mathrm{Cu}, \mathrm{Fe}, \mathrm{Pb}$ and $\mathrm{Cd}$ in stock solution is respectively $17.05 \mathrm{ppm}$, $16.75 \mathrm{ppm}, 4.06 \mathrm{ppm}$ and $4.55 \mathrm{ppm}$

\section{Column Tests: Removal Efficiency of Heavy Metals}

The effluent $\mathrm{pH}$ of aqueous sample from $5 \mathrm{~cm}$ port, $15 \mathrm{~cm}$ port and $25 \mathrm{~cm}$ port in each column was measured. According to the results, the $\mathrm{pH}$ was increased to a range of 6.0-8.9 in the first three days of operations (Fig. 6). Except for CSB and BCT + CSB mix, $\mathrm{pH}$ remained stable in all other columns until the end of the experiments. The CSB and BCT + CSB mix's $\mathrm{pH}$ gradually decreasing to a 4.0-5.5 range is possibly due to a high flow in these two columns. The increase in $\mathrm{pH}$ at effluents could be explained by a reaction of biochar (CSB) which releases the carbonates and hydroxyl ions.

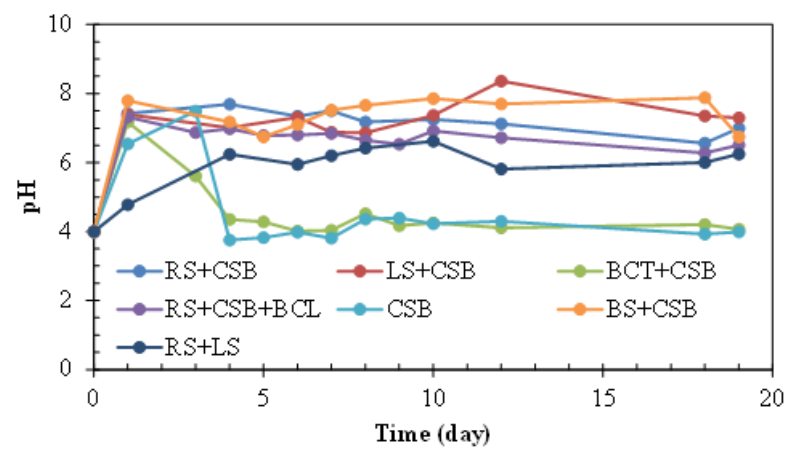

(a)

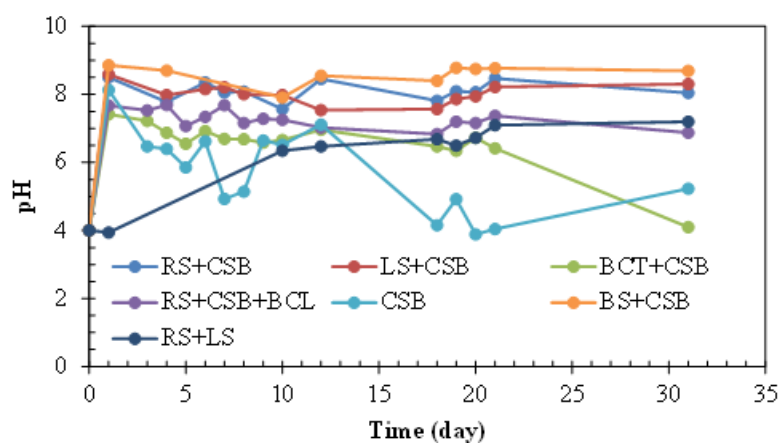

(b)

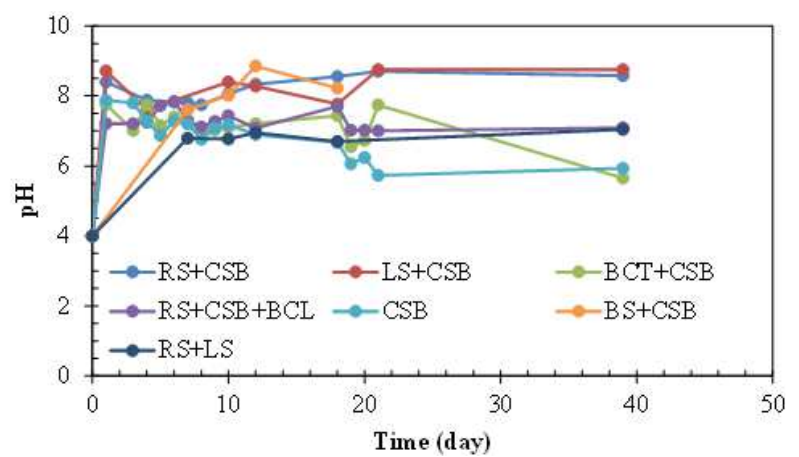

(c)

Fig. 6. Time course of $\mathrm{pH}$ in effluent (a) Port $5 \mathrm{~cm}$; (b) Port $15 \mathrm{~cm}$; (c) Port $25 \mathrm{~cm}$ 
In the column experiments, the initially raw value of $\mathrm{Cd}, \mathrm{Cu}, \mathrm{Fe}$ and $\mathrm{Pb}$ is respectively $4.55 \mathrm{ppm}, 17.05 \mathrm{ppm}$, $16.75 \mathrm{ppm}$ and $4.06 \mathrm{ppm}$. The initial $\mathrm{pH}$ of the solution is around 4.0. All the results are graphical illustrated in Fig. 7-10. Changes in total effluent concentrations were observed at the three sampling ports as a function of the testing time (Fig. 7-10). The removal efficiencies of metal elements on the column A-G at all ports is increasing similarly over the time of the experiments. It should be noted that the removal efficiency is the difference between heavy metal concentration in stock solution and leaching solution, divided by heavy metal concentration in stock solution.

At the conclusion of experiments, the removal efficiency for Cd from the BCT + CSB mix and the CSB mix at all three ports and the RS + BCT + CSB mix at ports of $5 \mathrm{~cm}$ and $25 \mathrm{~cm}$ gradually dropped down with a rate of $33.8 \%, 15.25 \%$ and $56.65 \%$, respectively, at the 5 $\mathrm{cm}$ port, $15.25 \%$ and $2034 \%$, respectively, at the $15 \mathrm{~cm}$ port and $29.5 \%, 30.67 \%$ and $77.79 \%$, respectively at the $25 \mathrm{~cm}$ port (Fig. 7).

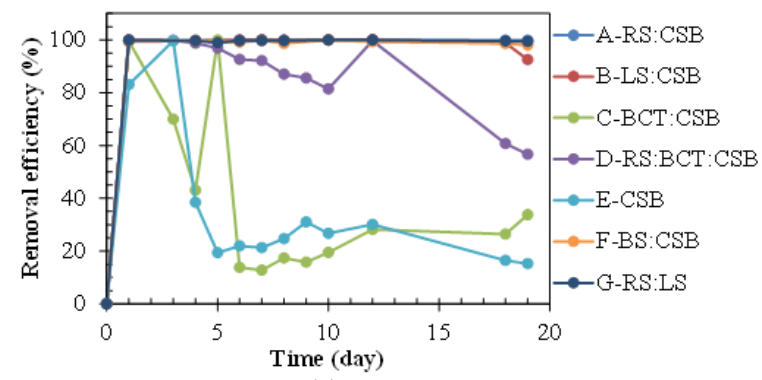

(a)

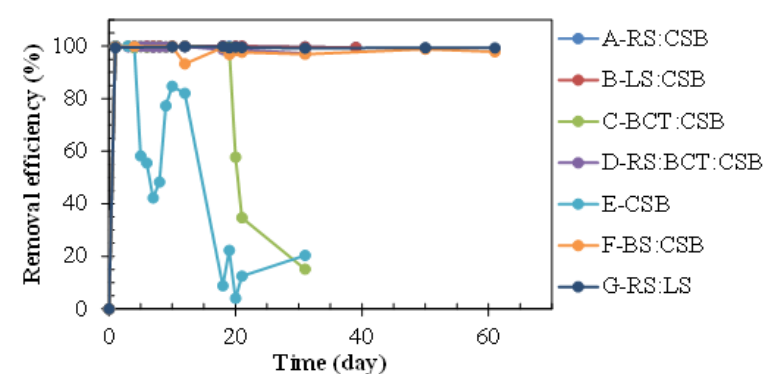

(b)

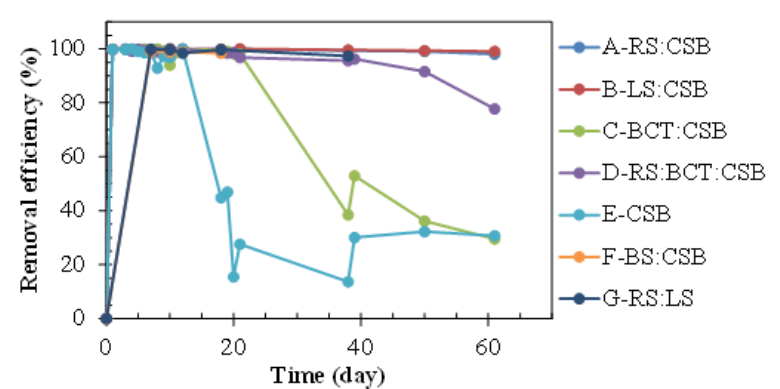

(c)

Fig. 7. Contaminant removal efficiency of $\mathrm{Cd}^{+2}$ (a) Port 5 $\mathrm{cm}$; (b) Port $15 \mathrm{~cm}$; (c) Port $25 \mathrm{~cm}$
It dropped down because the flow rates in these columns were high (Fig. 11). Besides the columns C, E and D (at ports $5 \mathrm{~cm}$ and $25 \mathrm{~cm}$ ), the removal efficiency of $\mathrm{Cd}$ became stable at around $99.0 \%$. Therefore, the reactive materials filled in column A, B, F and G are possible to remove $\mathrm{Cd}$ effectively from contaminated water, with a maximum of $99.0 \%$.

The removal efficiency of $\mathrm{Cu}$ in columns $\mathrm{C}$ and $\mathrm{E}$ at the $5 \mathrm{~cm}$ port also gradually decreases with a rate of $59.44 \%$ and $36.28 \%$, respectively. At the $25 \mathrm{~cm}$ port, the removal efficiency of $\mathrm{Cu}$ in columns $\mathrm{C}$ and $\mathrm{E}$ is $31.44 \%$ and $9.94 \%$, respectively. The removal efficiency of $\mathrm{Cu}$ in other five columns remains slightly stable as shown clearly in Fig. 8, with the maximum removal efficiency of around $99.8 \%$ for $\mathrm{Cu}$.

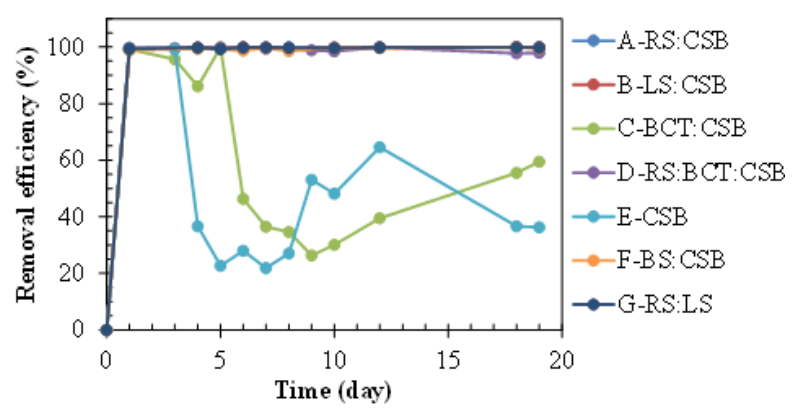

(a)

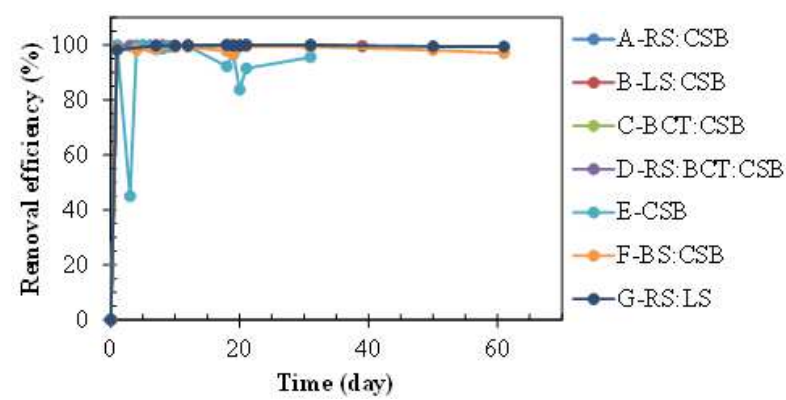

(b)

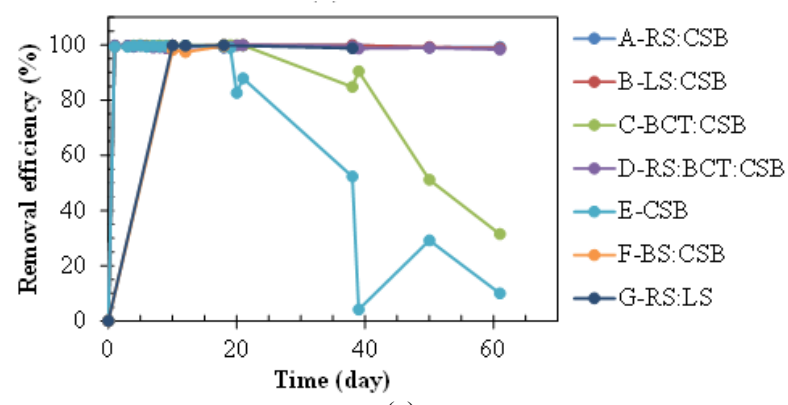

(c)

Fig. 8. Contaminant removal efficiency of $\mathrm{Cu}^{+2}$ (a) Port 5 cm; (b) Port $15 \mathrm{~cm}$; (c) Port $25 \mathrm{~cm}$ 


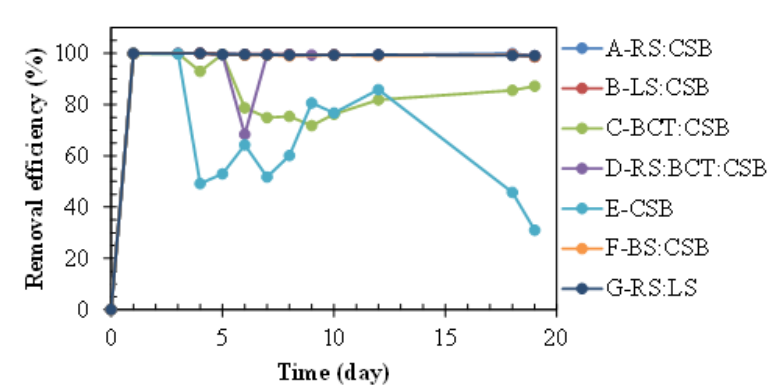

(a)

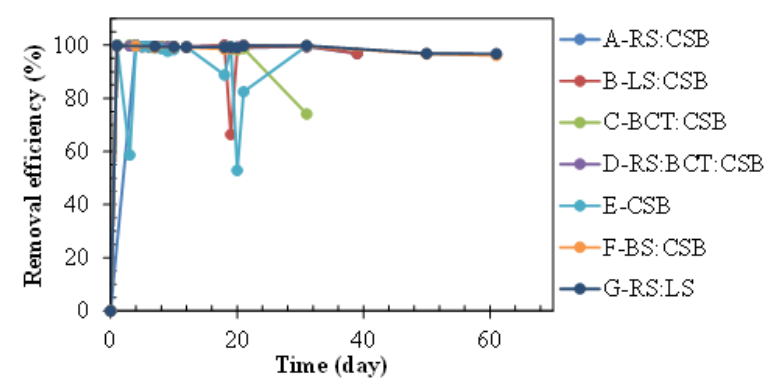

(b)

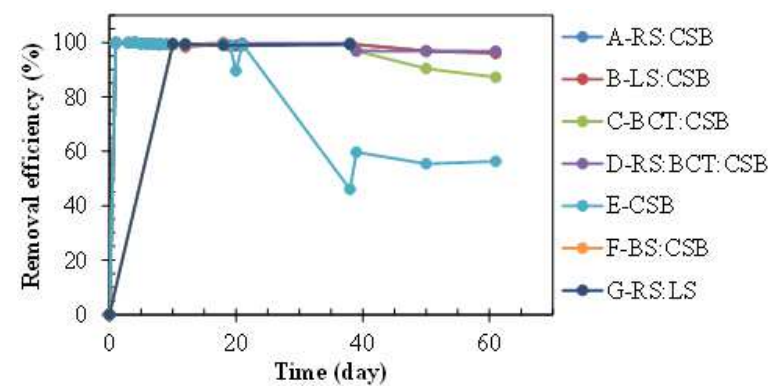

(c)

Fig. 9. Contaminant removal efficiency of $\mathrm{Fe}^{+2}$ (a) Port 5 cm; (b) Port $15 \mathrm{~cm}$; (c) Port $25 \mathrm{~cm}$

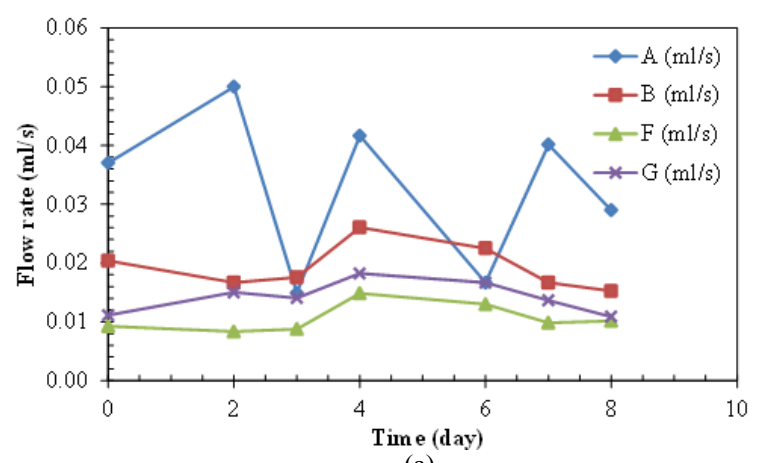

(a)

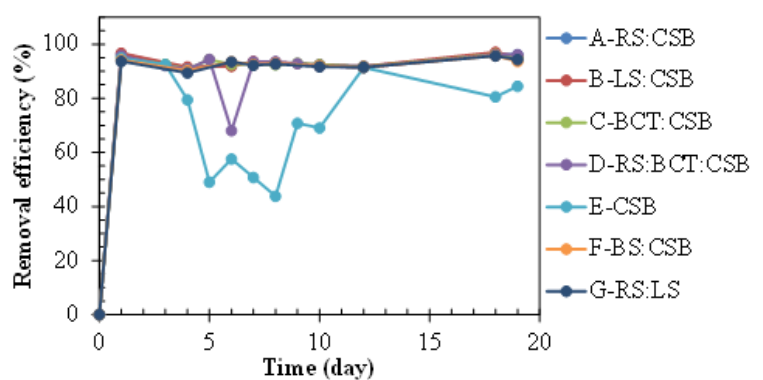

(a)

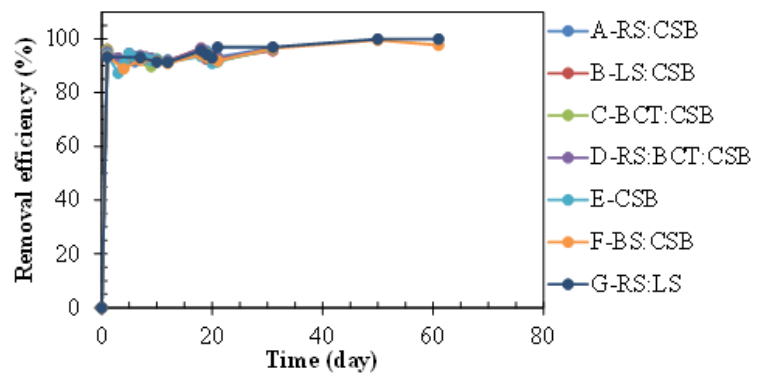

(b)

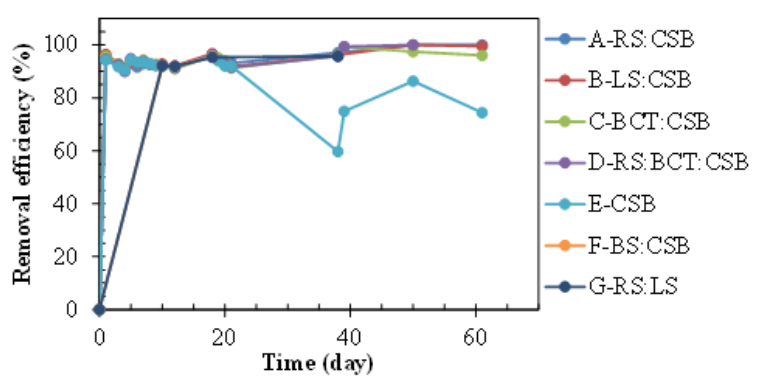

(c)

Fig. 10. Contaminant removal efficiency of $\mathrm{Pb}^{+2}$ (a) Port 5 $\mathrm{cm}$; (b) Port $15 \mathrm{~cm}$; (c) Port $25 \mathrm{~cm}$

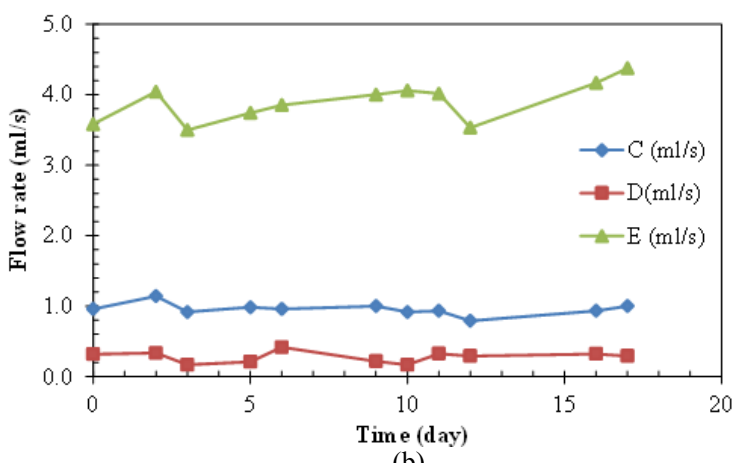

(b)

Fig. 11. Flow rate from (a) columns A, B, F and G; (b) columns C, D and E

The Fe removal efficiency of reactive materials in column $\mathrm{C}$ was decreased with a rate of $31.03 \%, 74.11 \%$ and $87.213 \%$ in port $5 \mathrm{~cm}, 15 \mathrm{~cm}$ and $25 \mathrm{~cm}$, respectively. In column $\mathrm{E}$, the Fe removal efficiency was also decreased with a rate of $87.14 \%, 56.3 \%$ at port of 5 $\mathrm{cm}$ and $25 \mathrm{~cm}$, respectively; and it was increased with a rate of $99.8 \%$ at the port of $15 \mathrm{~cm}$ (Fig. 9). For the other columns at the sampling port of $15 \mathrm{~cm}$ and $25 \mathrm{~cm}$, the 
removal efficiency of $\mathrm{Fe}$ decreases approximately to $96.8 \%$, while it is about $99.1 \%$ at the port $5 \mathrm{~cm}$.

The removal efficiency of $\mathrm{Pb}$ on the columns $\mathrm{A}, \mathrm{B}$, $\mathrm{C}, \mathrm{D}, \mathrm{F}$ and $\mathrm{G}$, are more than $93.7 \%$ at port $5 \mathrm{~cm}$, more than $95.65 \%$ at the port $15 \mathrm{~cm}$ and more than $95.66 \%$ at the port $25 \mathrm{~cm}$. At the column E at the port $5 \mathrm{~cm}$ and $25 \mathrm{~cm}$, the removal efficiency was decreased with a rate of $84.5 \%$ and $74.4 \%$, respectively. The effluent flow rate from the seven columns was measured weekly (Fig. 11). The flow from columns C, $\mathrm{D}$ and $\mathrm{E}$ is higher than that from columns $\mathrm{A}, \mathrm{B}, \mathrm{F}$ and G. This was expected as the hydraulic conductivity of reactive materials in columns $\mathrm{C}, \mathrm{D}$ and $\mathrm{E}$ is higher than that of the other reactive materials in columns $\mathrm{A}$, $\mathrm{B}, \mathrm{F}$ and $\mathrm{G}$.

\section{Conclusion}

In this research, the locally available reactive materials, i.e., Red Soil (RS), Laterite Soil (LS), Bangadeniya Soil (LS), Burnt Clay Tile (BCT) and Coconut Shell Biochar (CSB) show its potential in remediating the heavy metal contaminant in the groundwater. It is expected that the materials are potentially used to replace the high cost reactive materials, for example, Activated Carbon (AC), ZeroValent iron (ZVR) or Zeolite (Zeo) that are highly efficient to remove the metal elements and commonly used in developed countries.

The single reactive material of $\mathrm{CSB}$ and reactive material mixtures such as RS + CSB, $\mathrm{LS}+\mathrm{CSB}, \mathrm{BS}+$ $\mathrm{CSB}, \mathrm{BCT}+\mathrm{CSB}$ (with a weight ratio of 50:50) and $\mathrm{RS}+\mathrm{BCT}+\mathrm{CSB}$ (with a weight ratio of 100/3:100/3: $100 / 3$ ) used as PRB adsorbents were tested for removing the $\mathrm{Cd}(\mathrm{II}), \mathrm{Cu}(\mathrm{II}), \mathrm{Fe}(\mathrm{II})$ and $\mathrm{Pb}(\mathrm{II})$ from the synthetic water solutions carried out through the laboratory column experiment. The hydraulic conductivity of both single and mixed reactive materials was determined. It is one of important parameters for the PRB design. After the test, the hydraulic conductivity of CSB and BCT + CSB (with a ratio of 50:50) is greater than the suggested value of $10^{-4} \mathrm{~cm} / \mathrm{s}$, with $1.4 \times 10^{-4} \mathrm{~cm} / \mathrm{s}$ and $1.2 \times 10^{-4} \mathrm{~cm} / \mathrm{s}$, respectively, while $\mathrm{RS}+\mathrm{CSB}, \mathrm{LS}+\mathrm{CSB}, \mathrm{BS}+\mathrm{CSB}$, $\mathrm{RS}+\mathrm{LS}$ and $\mathrm{RS}+\mathrm{BCT}+\mathrm{CSB}$ have a value of $5.44 \times 10^{-5} \mathrm{~cm} / \mathrm{s}, 5.40 \times 10^{-5} \mathrm{~cm} / \mathrm{s}, 7.10 \times 10^{-6} \mathrm{~cm} / \mathrm{s}$, $5.60 \times 10^{-5} \mathrm{~cm} / \mathrm{s}$ and $6.90 \times 10^{-5} \mathrm{~cm} / \mathrm{s}$, respectively.

The experimental column studies are very important to estimate the removal efficiency of heavy metal contaminants in the water and provide the useful information to design the PRB system in the field. At the end of the experiment, the removal efficiencies of reactive materials filled in the column $\mathrm{A}(\mathrm{RS}+\mathrm{CSB})$, column B $(\mathrm{LS}+\mathrm{CSB})$, column D $(\mathrm{RS}$ $+\mathrm{BCT}+\mathrm{CSB})$, column F $(\mathrm{BS}+\mathrm{CSB})$ and column $\mathrm{G}$
$(\mathrm{RS}+\mathrm{LS})$ are very efficient, with the removal efficiencies of more than $90 \%$, except $\mathrm{Cd}$ that only in column $\mathrm{C}(\mathrm{BCT}+\mathrm{CSB})$, the removal efficiency is less than $90 \%$. Moreover, the removed concentrations of heavy metals from these columns are smaller than that of the maximum permissible level of Sri Lanka Standards for potable water - SLS 614, 1983. On the other hand, the removal efficiencies of reactive materials filled in columns $\mathrm{C}$ and $\mathrm{E}$ were low in comparing with the other five columns.

Since the flow rate are not the same in different columns, it is recommended that the analysis of column experiments as a function of pore volume should be taken into account. It is defined as $t Q / V$, where $t$ is the time, $Q$ is the flow rate and $V$ is the pore volume.

\section{Acknowledgement}

The authors would like to express a sincere thanks to the Norwegian Programme for Capacity Development in Higher Education and Research for DevelopmentNORHED, via Water and Society project, for financially supporting this research study.

\section{Author's Contributions}

Somean Yin: Conducted all experiments, data analysis and preparation of the draft manuscript.

Gemunu Herath: Refined research framework and coordinated the experimental operations.

Sokchhay Heng: Advised research design, organized the manuscript's structures and edited the manuscript.

Senajith Kalpage: Provided idea on setting up research methodology and operation of experiments.

\section{Ethics}

This article contains unpublished and original work of the authors. All authors have read and approved the manuscript and no ethical issues involved.

\section{References}

Afridi, H.I., T.G. Kazi, N.G. Kazi, M.B. Arain and N. Jalbani et al., 2009. Evaluation of arsenic, cobalt, copper and manganese in biological samples of steel mill workers by electrothermal atomic absorption spectrometry. Toxicol. Industrial Health, 25: 59-69. DOI: $10.1177 / 0748233709103036$

Arain, M.B., T.G. Kazi, M.K. Jamali, N. Jalbani and H.I. Afridi et al., 2008. Total dissolved and bioavailable elements in water and sediment samples and their accumulation in Oreochromis mossambicus of polluted Manchar Lake. Chemosphere, 70: 1845-1856.

DOI: 10.1016/j.chemosphere.2007.08.005 
Bermudez, G.M.A., R. Jasan, R. Plá and M.L. Pignata, 2011. Heavy metal and trace element concentrations in wheat grains: Assessment of potential noncarcinogenic health hazard through their consumption. J. Hazardous Mater., 193: 264-271. DOI: $10.1016 /$ j.jhazmat.2011.07.058

Blowes, D.W., C.J. Ptacek, S.G. Benner and C.W.T. McRae, 1998. Treatment of dissolved metals using permeable reactive barriers. Proceedings of the Groundwater Quality Conference, Sept. 21-25, IAHS, Germany, pp: 483-490.

Bone, B.D., 2012. Review of UK guidance on permeable reactive barriers. Proceedings of the Taipei International Conference on Remediation and Management of Soil and Groundwater Contaminated Sites, Oct. 30-31, pp: 611-768.

Carey, M.A., B.A. Fretwell, N.G. Mosley and J.W.N. Smith, 2002. Guidance on the use of permeable reactive barriers for remediating contaminated groundwater. National Groundwater and Contaminated Land Centre Report NC/01/51, Environment Agency, Bristol, UK.

Conca, J., E. Strietelmeier, N. Lu, S.D. Ware and T.P. Taylor et al., 2002. Treatability study of Reactive Materials to Remediate Ground Water Contaminated with Radionuclides, Metals and Nitrates in a Four-Component Permeable Reactive Barrier. In: Groundwater Remediation of Trace Metals, Radionuclides and Nutrients, with Permeable Reactive Barriers, Naftz, S., J.A. Morrison and C.C. Fuller (Eds.), Academic Press, San Diego, CA, pp: 221-252.

Dong, J., Y.S. Zhao, W.H. Zhang and M. Hong, 2009. Laboratory study on sequenced permeable reactive barrier remediation for landfill leachatecontaminated groundwater. J. Hazardous Mater., 161: 224-230. DOI: 10.1016/j.jhazmat.2008.03.086

Evanko, C.R. and D.A. Dzombak, 1997. Remediation of metals-contaminated soils and groundwater. Ground-Water Remediation Technologies Analysis Center, Pittsburg.

Garbarino, J.R., H. Hayes, D. Roth, R. Antweider and T.I. Brinton et al., 1995. Contaminants in the Mississippi River, 1987-92. USGS, Denver.

Gibert, O., T. Rötting, J.L. Cortina, J.D. Pablo and C. Ayora et al., 2011. In-situ remediation of acid mine drainage using a permeable reactive barrier in Aznalcóllar (Sw Spain). J. Hazardous Mater., 191: 287-295. DOI: 10.1016/j.jhazmat.2011.04.082

Guerin, T.F., S. Horner, T. McGovern and B. Davey, 2002. An application of permeable reactive barrier technology to petroleum hydrocarbon contaminated groundwater. Water Res., 36: 15-24.

DOI: $10.1016 / \mathrm{S} 0043-1354(01) 00233-0$
Guzel, F., H. Yakuth and G. Topal, 2008. Determination of kinetic and equilibrium parameters of the batch adsorption of $\mathrm{Mn}(\mathrm{II})$, $\mathrm{Co}(\mathrm{II}), \mathrm{Ni}(\mathrm{II})$ and $\mathrm{Cu}(\mathrm{II})$ from aqueous solution by black carrot (Daucus carota L.) residues. J. Hazardous Mater., 153: 1275-1287.

DOI: 10.1016/j.jhazmat.2007.09.087

Han, W., F. Fu, Z. Cheng, B. Tang and S. Wu, 2015. Studies on the optimum conditions using acidwashed zero-valent iron/aluminum mixtures in permeable reactive barriers for the removal of different heavy metal ions from wastewater. J. Hazardous Mater., 302: 437-446. DOI: 10.1016/j.jhazmat.2015.09.041

Henderson, A.D. and A.H. Demond, 2007. Long-term performance of zero-valent iron permeable reactive barriers: a critical review. Environ. Eng. Sci., 24: 401-423.

DOI: $10.1089 /$ ees.2006.0071

Kaandeepan, V., K. Nitharsan and P. Ravikumar, 2012. Leachate treatment using reactive barrier. University of Peradeniya, Peradeniya.

Kao, C.M. and L. Yang, 2000. Enhanced bioremediation of trichloroethene contaminated by a biobarrier system. Water Sci. Technol., 42: 429-434.

Kazi, T.G., N. Jalbani, N. Kazi, M.B. Arain and M.K. Jamali et al., 2009. Estimation of toxic metals in scalp hair samples of chronic kidney patients. Biol. Trace Element Res., 127: 16-27. DOI: $10.1007 / \mathrm{s} 12011-008-8222-8$

Kober, R., D. Schafer, M. Ebert and A. Dahmke, 2002. Coupled in-situ reactors using $\mathrm{Fe}^{0}$ and activated carbon for the remediation of complex contaminant mixtures in groundwater. Proceedings of the Groundwater Quality 2001 Conference, (GQC' 02), IAHS, Sheffield, UK, pp: 18-21.

Kovalick, W.W. and J. Kingscott, 1995. Progress in cleanup and technological developments in U.S. Superfund Program. Proceedings of the 5th International FZK/TNO Conference on Contaminated Soil, (CCS' 95), Kluwer Academic Publishers, the Netherlands, pp: 29-38.

Liu, T., X. Yang, Z.L. Wang and X. Yan, 2013. Enhanced chitosan beads-supported $\mathrm{Fe}^{0}$ nanoparticles for removal of heavy metals from electroplating wastewater in permeable reactive barriers. Water Res., 47: 6691-6700. DOI: 10.1016/j.watres.2013.09.006

Marie, M., M. Amy and S. Jenna, 2009. Design of an exsitu permeable reactive barrier for the removal of arsenic in Cambodian groundwater for irrigation purposes. McGill University, Montreal. 
Meena, A.K., G.K. Mishra, P.K. Rai, C. Rajacopal and P.N. Nagar, 2005. Removal of heavy metal ions from aqueous solutions using carbon aerogel as an adsorbent. J. Hazardous Mater., 122: 161-170. DOI: 10.1016/j.jhazmat.2005.03.024

Munagapati, V.S., V. Yarramuthi, S.K. Nadavala, S.R. Alla and R. Abburi, 2009. Biosorption of $\mathrm{Cu}(\mathrm{II}), \mathrm{Cd}(\mathrm{II})$ and $\mathrm{Pb}(\mathrm{II})$ by Acacia leucocephala bark powder: Kinetics, equilibrium and thermodynamics. Chem. Eng. J., 157: 357-365. DOI: $10.1016 /$ j.cej.2009.11.015

Natale, F.D., A. Lancia, A. Molino and D. Musmarra, 2007. Removal of chromium ions form aqueous solutions by adsorption on activated carbon and char. J. Hazardous Mater., 145: 381-390. DOI: 10.1016/j.jhazmat.2006.11.028

O'Hannesin, S.F. and R.W. Gillham, 1998. Long-term performance of an in situ "iron wall" for remediation of VOCs. Groundwater, 36: 164-170. DOI: 10.1111/j.1745-6584.1998.tb01077.x

Obiri-Nyarko, F., S.J. Grajales-Mesa and G. Malina, 2014. An overview of permeable reactive barriers for in situ sustainable groundwater remediation. Chemosphere, 111: 243-259.

DOI: $10.1016 /$ j.chemosphere.2014.03.112
Soylak, M., L, Elci and M. Dogan, 1999. Flame atomic absorption spectrometric determination of cadmium, cobalt, copper, lead and nickel in chemical grade potassium salts after an enrichment and separation procedure. J. Trace Microprobe Techniques, 17: 149-156.

Thiruvenkatachari, R., S. Vigneswaran and R. Naidu, 2008. Permeable reactive barrier for groundwater remediation. J. Industrial Eng. Chem., 14: 145-156. DOI: $10.1016 /$ j.jiec.2007.10.001

Vignola, R., R. Bagatin, A.D.F. D’Aurisb, C. Flego and M. Nalli et al., 2011. Zeolites in a Permeable Reactive Barrier (PRB): One year of field experience in a refinery groundwater-Part 1: The performances. Chem. Eng. J., 178: 204-209. DOI: 10.1016/j.cej.2011.10.050

Woinarski, A.Z., G.W. Stevens and I. Snape, 2006. A natural zeolite permeable reactive barrier to treat heavy-metal contaminated waters in Antarctica: Kinetic and fixed-bed studies. Process Safety Environ. Protect., 84: 109-116.

DOI: $10.1205 /$ psep.04296 